ISSN 0103-5150

Fisioter. Mov., Curitiba, v. 29, n. 1, p. 95-102, Jan./Mar. 2016

Licenciado sob uma Licença Creative Commons

DOI: http://dx.doi.org.10.1590/0103-5150.029.001.A010

(c)

\title{
Respiratory function and functional capacity in chronic stroke patients ${ }^{1}$
}

\author{
Avaliação respiratória e capacidade funcional \\ em pacientes com AVE crônico
}

\section{Anna Cláudia Martinez Machado ${ }^{[a]}$, Nathália Grasielle Marinho Silva ${ }^{[a]}$, Gisele do Carmo Leite Diniz ${ }^{[a]}$, Bruno Porto Pessoa ${ }^{[b]}$, Paula Luciana Scalzo ${ }^{[c] *}$}

[a] Pontifícia Universidade Católica de Minas Gerais (PUC Minas), Betim, MG, Brazil

[b] Centro Universitário Triângulo (UNITRI), Uberlândia, MG, Brazil

[c] Universidade Federal de Minas Gerais (UFMG), Belo Horizonte, MG, Brazil

\section{Abstract}

Introduction: Cerebrovascular accident (CVA) or stroke results in weakness of the trunk muscles and physical unfitness. Objectives: To evaluate respiratory changes caused by stroke and correlate them with the functional capacity of chronic stroke patients who were treated at the Clinical Center of Physical Therapy of the Pontifical Catholic University of Minas Gerais, Betim. Methods: Fifteen patients were recruited for assessment of respiratory function and functional capacity. We measured maximum inspiratory pressure (MIP), maximal expiratory pressure (MEP), peak expiratory flow (PEF), vital capacity (VC), and functional capacity using the six-minute walk test (6MWT). Test results were compared with reference values using an

1 Study conducted at the Physical Therapy Clinic of the Pontifical Catholic University of Minas Gerais, Betim, Brazil.

* ACMM: grad, e-mail: annaclaudia.mm@gmail.com NGMS: grad, e-mail:, nathalia_grasielle@hotmail.com GCLD: MSc, e-mail: giselediniz@superig.com.br BPP: MSc, e-mail: pessoabh2@yahoo.com.br PLS: PhD, e-mail: paula.scalzo@ig.com.br 
unpaired Student's t-test or the Mann-Whitney test. Respiratory variables were correlated with the distance walked in the 6MWT using Spearman's correlation test. Results: The sample had a mean age of $58.2 \pm 13.4$ years, and most patients had a diagnosis of ischemic stroke and left hemiparesis. The following values were obtained: MIP (47.7 $\pm 22.2 \mathrm{cmH} 20)$; MEP ( $47.5 \pm 20.3 \mathrm{cmH} 20)$; PEF (351.3 $\pm 90.8 \mathrm{~L} / \mathrm{min}) ; \mathrm{VC}(3.0 \pm 0.91 \mathrm{~L})$; and 6MWT (222.4 $\pm 101.6 \mathrm{~m})$. The MIP, MEP, PEF, and 6MWT values measured in this study were statistically significantly lower $(\mathrm{p}<0.001)$ than the reference values. There was no statistically significant correlation between the distance walked in the 6 MWT and respiratory variables $(p>0.005)$. Conclusion: Our results suggest that, despite the decrease in respiratory muscle strength, PEF, and VC, these variables did not correlate with the functional capacity of the chronic stroke patients assessed in this study.

Keywords: Stroke. Vital capacity. Respiratory mechanics. Respiratory muscles.

\section{Resumo}

Introdução: $O$ acidente vascular encefálico (AVE) resulta em fraqueza dos músculos do tronco e descondicionamento físico. Objetivos: Avaliar as alterações respiratórias e correlacioná-las com a capacidade funcional de pacientes pós AVE crônicos do Centro Clínico de Fisioterapia da PUC Minas Betim. Métodos: Foram recrutados 15 pacientes para avaliação respiratória e da capacidade funcional. Foram avaliadas a pressão inspiratória máxima (PImáx), pressão expiratória máxima (PEmáx), pico de fluxo expiratório (PFE), capacidade vital (CV) e a capacidade funcional a partir do teste de caminhada de seis minutos (TC6M). Os resultados foram comparados com os valores de referência utilizando os testes t de Student não pareado ou teste Mann-Whitney. As variáveis respiratórias foram correlacionadas com a distância percorrida no TC6M por meio do Coeficiente de Correlação de Spearman. Resultados: A amostra apresentou idade média de 58,2 \pm 13,4 anos, sendo que o diagnóstico da maioria foi AVE isquêmico e hemiparesia à esquerda. Os valores obtidos foram PImáx (47,722,2 $\mathrm{cm} \mathrm{H}_{2} \mathrm{O}$ ); PEmáx (47,5 20,3 $\mathrm{cmH}_{2} \mathrm{O}$ ); PFE (351,390,8 L/min); CV (3,00,91 L) e TC6m (222,4101,6 m). Quando comparados com os valores de referência, os valores de PImáx, PEmáx, PFE e TC6M foram estatisticamente menores $(p<0,001)$. Não houve correlação estatisticamente significativa entre a distância percorrida no TC6M e as variáveis respiratórias ( $p>0,005)$. Conclusão: Os resultados sugerem que apesar de existir o declínio da força muscular respiratória, do PFE e da CV, esses não se correlacionaram com a capacidade funcional dos pacientes pós AVE crônicos avaliados.

Palavras-chave: Acidente vascular encefálico. Capacidade vital. Mecânica respiratória. Músculos respiratórios.

\section{Introduction}

The generation and maintenance of respiratory rate and ventilation depend on the integrity of the nervous system, which determines neural control by means of voluntary and automatic mechanisms. Automatic control is mediated by neuronal groups in the brainstem, while voluntary control is mediated by cortical centers that are located in the contralateral motor cortex (1). This neural control allows the coordinated activity of the respiratory muscles $(1,2)$. The diaphragm stands out among the respiratory muscles whose primary function is to allow the rhythmic and continuous movement of the chest wall and abdomen (2). It is the main respiratory muscle and has greater oxidative capacity and capillary density than other respiratory muscles, which gives it greater resistance to fatigue.
Associated diseases of the respiratory and neurological system such as cerebrovascular accident (CVA) or stroke can cause changes in respiratory rate and ventilation. The clinical picture of post-stroke individuals can be quite diverse depending on the location and extent of the vascular injury, and may contribute to the development of respiratory insufficiency or failure (3-5).

Studies show changes in latency, amplitude of action potentials and excitability threshold of respiratory muscles, as well as decreased diaphragmatic excursion and excursion of intercostal muscles of the paretic side during voluntary ventilation $(4,5)$. Moreover, muscle weakness (hemiparesis) contralateral to the brain injury - which is the most common clinical manifestation after stroke - may indirectly compromise the stabilization of the spine, which 
affects thoracic mobility and respiratory muscle strength, and hampers respiratory mechanics (3-5).

of note, post-stroke individuals, in addition to motor and sensory losses, also have decreased physical fitness, which results in a sedentary lifestyle and perpetuates a vicious cycle of inactivity. Thus, the decline in neuromuscular function is accelerated, which increases the likelihood of occurrence of other comorbidities and promotes disability $(7,8)$. The modification of the cortical control of ventilation, as well as the decline in motor function and functional capacity in these individuals are well documented. The literature on changes in muscle strength and respiratory pattern, and their consequences to these individuals, however, is still in its infancy. Thus, this study aimed to assess respiratory changes caused by stroke and correlate them with the functional capacity of patients after chronic stroke treated at the Clinical Center of Physical Therapy of the Pontifical Catholic University of Minas Gerais, Betim.

\section{Material and Methods}

The study project was approved by the Research Ethics Committee of the Pontifical Catholic University of Minas Gerais (CAAE: 0242.0:213,000-09). This cross-sectional study recruited patients from the neurological outpatient clinic of the Clinical Center of Physical Therapy of the Pontifical Catholic University of Minas Gerais, Betim, Brazil. Inclusion criteria were: clinical diagnosis of stroke associated with motor deficit contralateral to the injury; being able to understand and follow verbal commands during tests; and being able to walk independently or with assistive devices. Exclusion criteria were: having other neurological diseases; and having taken part in specific respiratory muscle training programs in the three months prior to study entry. Participants or caregivers were briefed on the purpose and procedures of the study and signed an informed consent form.

All participants underwent complete physical examination. Then inspiratory and expiratory muscle strength, peak expiratory flow, vital capacity and functional capacity were measured using standard techniques. All measurements were performed by the same previously trained examiners. Patients' functional outcome was assessed using the modified Rankin Scale (9-11). The score ranges from 0 (no disability) to 6 (severe disability).
Respiratory muscle strength was assessed by measuring mouth pressures during maximal inspiratory pressure (MIP) and maximal expiratory pressure (MEP) against a manometer (Commercial Medical, M120, São Paulo). MIP and MEP were measured according to a standardized technique by Neder et al (12). Patients were asked to press their lips against the mouthpiece of the instrument as tighly as possible in order to avoid air leaks. The examiners also helped participants by pressing their lips and cheeks (13). Patient's cheeks were compressed with the palms in order to prevent the action of the facial muscles (14).

Peak expiratory flow (PEF) was measured with a Peak Flow Meter (Asses Peak Flow Meter, Health Scan Products, Inc., Cedar Grove, NJ, USA). Participants were asked to perform maximal inspiration and then a maximal, forced, short, explosive expiration. Patients were not allowed to cough during the test and were asked to keep their lips tightly pressed to the mouthpiece in order to avoid air leaks. Three measurements were performed for each patient and the highest value of the three measurements was recorded.

Vital capacity was measured with a Wright spirometer (Ferraris, UK). Patients had their nose clipped and were in the sitting position with their trunk at an angle of $90^{\circ}$ to their thighs and their feet on the floor. Participants were instructed to make a maximal inspiration through the ventilometer mouthpiece until total lung capacity was reached and then make a maximum expiration until residual volume was reached. Three measurements were performed for each patient and the highest value of the threemeasurements was recorded.

Functional capacity was assessed using the sixminute walk test (6MWT), according to the guidelines of the American Thoracic Society (15). The following devices were used to perform the test: timer (digital timer, Herweg, São Paulo), pulse oximeter (Model BCI Digit INC, USA), heart-frequency meter (Blitz ${ }^{\circledR}$ frequency meter), sphygmomanometer, stethoscope (BD ${ }^{\circledR}$, Germany), and modified Borg Scale (16).

The variables were expressed as mean \pm standard deviation (SD). The normal distribution of each variable was was determined by using the KolmogorovSmirnov test. Test results were compared with reference literature values using an unpaired Student's t-test or the Mann-Whitney test. We also compared results between patients according to the type (ischemic or hemorrhagic) and topography of the stroke 
(left or right hemisphere lesion location). Respiratory variables were correlated with the distance walked in the 6MWT using Spearman's correlation test. We used an unpaired Student's t-test or the Wilcoxon's test to compare the physiological responses measured before and after the 6MWT. The statistical program used was SPSS 15.0 (SPSS Inc, Chicago, Ill). The significance level was set at $\mathrm{p}<0.05$.

\section{Results}

Fifteen patients ( 7 men and 8 women) participated in this study. Mean age was $58.2 \pm 13$.4 years and mean time of diagnosis was $3.7 \pm 1.9$ years (range, 1-8 years). Eight patients had had ischemic stroke and seven had had hemorrhagic stroke. Most subjects had left hemiparesis $(n=11)$. With regard to associated diseases, $13(66 \%)$ patients were undergoing treatment for high blood pressure (hypertension). As regards lifetyle habits, $12(80 \%)$ patients were smokers and $11(73,3 \%)$ self-declared not practicing any physical activity (Table 1 ).

Table 1- Anthropometric and clinical data of study participants

\begin{tabular}{lc}
\hline \multicolumn{1}{c}{ Variables } & $\begin{array}{c}\text { Chronic stroke subjects } \\
(\mathbf{n}=\mathbf{1 5})\end{array}$ \\
\hline Gender (M/F) & $7 / 8$ \\
Age (years) & $58.2(13.4)$ \\
Height $(\mathrm{m})$ & $1.59(0.08)$ \\
Weight $(\mathrm{Kg})$ & $66.93(12.41)$ \\
BMl $\left(\mathrm{Kg} / \mathrm{m}_{2}\right)$ & $25.87(4.29)$ \\
Number of years since first & $3.7(1.9)$ \\
stroke & \\
Side of hemiparesis (R/L) & $4 / 11$ \\
\hline
\end{tabular}

Note: Abbreviations: $\mathrm{M}=$ male; $\mathrm{F}=$ female; $\mathrm{BMI}=$ Body Mass Index; $R=$ right; $L=$ left. Data presented as mean \pm standard deviation.

According to the modified Rankin Scale, seven (47\%) subjects had grade 1, i.e., no functional deficit or ability to perform all usual activities and tasks. The other participants had either grade $2(33,3 \%)$ inability to perform all usual activities, but ability to perform personal activities independently - or grade
$3(20 \%)$ - requires help to perform activities of daily living, but is able to walk without help.

The following respiratory parameter values were obtained: MIP $\left(47.7 \pm 22.2 \mathrm{cmH}_{2} \mathrm{O}\right)$; MEP $(47.5 \pm 20.3$ $\left.\mathrm{cmH}_{2} \mathrm{O}\right)$; PEF $(351.3 \pm 90.8 \mathrm{~L} / \mathrm{min}) ;$ and VC $(3.0 \pm$ $0.91 \mathrm{~L}$ ). The mean distance walked in the 6MWT was $222.4 \pm 101.6 \mathrm{~m}$. As we can see in Table 2, the MIP, MEP, PEF and 6MWT values measured in this study were statistically lower $(p<0.001)$ than the reference values. There was no statistically significant difference only between the obtained and expected values of VC $(p=0.159)$. In the analysis by subgroups, there was no difference between variables for type of injury (hemorrhagic and ischemic). Nevertheless, PEF was statistically lower in the group with left hemiparesis, when compared with the group with right hemiparesis ( $\mathrm{p}$-values = $317.3 \pm 74.0$ and $45.0 \pm 65.6 \mathrm{~L} / \mathrm{min}$, respectively).

Table 2- Obtained and predicted values of respiratory measures and distance walked

\begin{tabular}{lccr}
\hline Variables & $\begin{array}{c}\text { Obtained } \\
\text { values }\end{array}$ & $\begin{array}{c}\text { Predicted } \\
\text { values }\end{array}$ & p-value \\
\hline MIP & $47.73(22.19)$ & $94.15(15.68)$ & $<\mathbf{0 . 0 0 1}$ \\
MEP & $47.46(20.27)$ & $97.69(20.84)$ & $<\mathbf{0 . 0 0 1}$ \\
PEF & $351.83(90.85)$ & $420.66(75.74)$ & $<\mathbf{0 . 0 0 1}$ \\
VC & $3010(907.32)$ & $3296(795.51)$ & 0.159 \\
6MWT & $222.37(101.65)$ & $519.83(94.22)$ & $<\mathbf{0 . 0 0 1}$ \\
\hline
\end{tabular}

Note: Abbreviations: MIP = maximal inspiratory pressure; MEP = maximal expiratory pressure; PEF = peak expiratory flow; $\mathrm{VC}=$ vital capacity; 6MWT = six-minute walk test.

Data presented as mean \pm standard deviation.

Table 3 shows the vital data values obtained in the 6MWT. There was a statistically significant difference in heart rate $(\mathrm{p}<0.001)$, respiratory rate $(\mathrm{p}$ $<0.001$ ) and perceived exertion as measured by the Borg Scale $(\mathrm{p}<0.001)$ before and after the 6MWT. Nevertheless, there was no significant difference in systolic blood pressure $(p=0.290)$, diastolic blood pressure $(\mathrm{p}=0.564)$ and oxygen saturation $(\mathrm{p}=$ 0.096 ) before and after the 6MWT. There was no statistically significant correlation between the distance walked in the 6MWT and any of the respiratory variables measured. 
Table 3 - Physiological responses to the six-minute walk test

\begin{tabular}{lccc}
\hline Variables & Before & After & P-value \\
\hline $\begin{array}{l}\text { SBP } \\
\text { (mmHg) }\end{array}$ & $128.00(11.46)$ & $131.33(18.07)$ & 0.290 \\
DBP & $76.00(5,07)$ & $78.67(11.25)$ & 0.564 \\
$(\mathrm{mmHg})$ & & & \\
HR (bpm) & $76.67(11.74)$ & $96,33(17.26)$ & $<\mathbf{0 . 0 0 1}$ \\
RR (irpm) & $18.53(3.56)$ & $21.47(3.38)$ & $<\mathbf{0 . 0 0 1}$ \\
Sa02 (\%) & $95.87(1.41)$ & $96.53(1.46)$ & 0.096 \\
Borg Scale & $0.87(0.97)$ & $3,33(2.06)$ & $<\mathbf{0 . 0 0 1}$ \\
\hline
\end{tabular}

Note: Abbreviations: $\mathrm{SBP}=$ systolic blood pressure, $\mathrm{DBP}=$ diastolic blood pressure, $\mathrm{HR}=$ heart rate, $\mathrm{RR}=$ respiratory rate, $\mathrm{SaO} 2$ $=$ oxygen saturation.

Data presented as mean \pm standard deviation.

\section{Discussion}

The main finding of this study was that patients had a decrease in respiratory muscle strength, peak expiratory flow rate and functional capacity. However, the respiratory changes did not affect the decline in functional capacity in our study sample. Our results corroborate other studies in which post-stroke subjects showed reduced respiratory muscle strength and consequent diaphragm and abdominal dysfunction (8). This reduction may be associated with several factors such as muscle tone changes, abdominal muscles weakness and lack of trunk control (17).

According to Pompeu et al. (18) the changes that occur in trunk control after a stroke may lead to breathing problems. This is consistent with the results obtained by Salmela et al. (19), who found decreased MIP and MEP values in post-stroke individuals, when compared with healthy subjects. A certain degree of abdominal spasticity would be beneficial to breathing because it would help expiration and support the inspiratory phase. However, marked abdominal spasticity in post-stroke patients makes diaphragm activity difficult because it ends up working as a blockade against the descent of the phrenic center. In some cases, this causes respiratory distress with excessive use of accessory muscles and hypoxemia, because the accessory muscles alone are not able to move suitable volumes of air to allow adequate pulmonary ventilation and gas exchange (20).

In addition to stroke-related factors, studies show that there is also a gradual reduction in overall muscle mass and muscle strength with increasing age. A study conducted with healthy older adults aged between sixty and ninety years has found a decrease in respiratory muscle strength in this age group and concluded that this is caused by sarcopenia (21). Given the relationship between MEP, abdominal and thoracic muscles, we highlight that low MEP denotes abdominal and chest muscles weakness (22).

There was a statistically significant difference between the actual distance walked in the 6MWT and the predicted values according to age and gender. This can be explained by the fact that most participants had a mobility deficit, which usually hampers the performance of the 6MWT by this population compared to healthy individuals of the same age. Nive patients used used assistive devices to walk. The mean distance walked in this study was less than $45 \%$ of the expected distance for these age groups (13). Corrêa et al. (23) quantified and compared muscle activity parameters and joint moments of the lower extremity during gait between healthy and post-stroke volunteers by using electromyography and electrogoniometry. These authors have concluded that reduced angular velocity is directly associated with increased levels of muscle co-activity in post-stroke patients. They have found that post-stroke patients show less mobility of the ankle joint, balancing phase changes and decreased speed of motion when compared to healthy volunteers. Muscle weakness in the entire hemibody associated with deficits in neural movement control make gait more energy costly for these patients (24). Muscle spasticity also contributes to this, because it hinders the skillful execution of movements, increasing the required energy demand and level of attention of the patient (22).

There were significant changes in vital data before and after the 6MWT, except for Sp02, SBP and DBP. Because aerobic exercises are dynamic in nature, they result in an increase in sympathetic nerve activity that is triggered by the activation of the central command and muscle mechanoreceptors. As a result, heart rate, end-systolic volume and cardiac output increase. The vasodilatation in the active muscles occurs due to the production of metabolites in the muscle, which causes reductions in peripheral vascular resistance. Thus, during dynamic exercise there is an increase in systolic blood pressure, while the diastolic blood pressure remains unchanged or decreases. As the sample of this study consisted of patients after chronic stroke in whom the affected 
hemibody is unable to properly activate the muscles, their responses to exercise are altered. During the $6 \mathrm{MWT}$, individuals with physical limitations are incapable of walking the distances expected for their age because of their low walking speed. This is probably due to lack of activation or inappropriate activation of the muscles of the compromised lower limbs. According to Forjaz et al. (26), there is no change in blood pressure is if the exercise is performed at an intensity below the anaerobic threshold. Moreover, the greater the muscle mass exercised dynamically, the greater the increase in heart rate, but the smaller the increase in blood pressure. Thus, these patients make up for the weakness of the compromised hemibody by activating more muscle mass in the noncompromised lower limb. The difficulty ito exercise at higher intensities is due to the substitution of type 1 fibers with type 2 fibers. This leads to typical muscle fatigue in these patients. In addition, the energy expenditure required to perform normal gait increases approximately 1.5 to 2 -fold in post-stroke subjects compared with healthy individuals (27).

Contrary to the results of this study, a study that evaluated the respiratory muscle strength and functional capacity of asymptomatic adults aged between 65 and 75 years has found correlations between respiratory measures and the 6MWT (25). The results of this study could be probably explained by the fact that the reductions in the distances walked in the 6MWT were influenced by specific global features (disabilities) that were caused by the stroke and not by changes in respiratory mechanics. The low aerobic endurance observed in post-stroke individuals is probably due to a decreased recruitment of motor units during dynamic activity, reduced oxidative capacity of paretic muscles and an overall decrease in aerobic endurance with increased energy expenditure during submaximal exercises $(19,28$ - 30).

Therefore, all the factors that affect post-stroke individuals added to physiological characteristics of aging limit the overload of the respiratory system during submaximal exercise. Further studies could elucidate if these factors are more important in reducing the distances walked or the respiratory muscle strength, expiratory flow and vital capacity. Two major limitations of this study are the reduced sample size and the heterogeneity of the sample with respect to physical functionality and age.

\section{Conclusion}

Our study showed that patients had a decrease in respiratory muscle strength, peak expiratory flow rate and functional capacity. However, the respiratory changes did not correlate with the decline of functional capacity.

\section{Acknowledgments}

We would like to thank the funding institutions PROBIC/FAPEMIG for their support of this project.

\section{References}

1. De Troyer, A. Respiratory muscle function. in: Cherniack Neils, Altose Murray D, Homma Ikuo. Rehabilitation of the patient with respiratory disease. Editora McGraw-Hill professional; 1990. cap. 3, p. 21-32.

2. Cohen E. et al. Diaphragmatic movement in hemiplegic patients measured by ultrasonography. Thorax. 1994;49: 890-95.

3. Laghi F, Tobin MJ. Disorders of the respiratory muscles. Am J Respir Crit Care Med. 2003; 68, 10-48.

4. Similowski $\mathrm{T}$ et al. Impairment of central motor conduction to the diaphragm in stroke. American Journal of Respiratory and Clinical Care Medicine. 1996;154(2):436-41.

5. Inácio $\mathrm{E}$ et al. Força muscular e padrão respiratório em hemiplégicos crônicos. Revista Brasileira de Fisioterapia. 2004, Supplem, 92.

6. Lanini B et al. Chest wall kinematics in patients with hemiplegia. American Journal of respiratory and critical care medicine. 2003;168(1):109-13.

7. Rubint RS; Zorrati, SRR. Perfil epidemiológico de pacientes vítimas de acidente vascular encefálico atendidos em hospital secundário, Fisio Brasil: Atualização Científica. 2004;64: 7-11.

8. Meneghetti CHZ, Figueiredo VE, Guedes CAV, Batissela ACT. Avaliação da força muscular respiratória em indivíduos acometidos por acidente vascular encefálico. Rev Neurocienc. 2011;19(1):56-60. 
9. Guimaraes RB, Guimaraes RB. Validação e adaptação cultural para a língua portuguesa de escalas de avaliação funcional em doenças cerebrovasculares: uma tentativa de padronização e melhora da qualidade de vida. Rev Bras Neurol. 2004;40(3):5-13.

10. Soriano FFS, Baraldi K. Escalas de avaliação funcional aplicáveis a pacientes pós acidente vascular encefálico. ConScientiae Saúde. 2010;9(3):521-30.

11. Caneda MAG, Fernandes JG, Almeida AG, Mugnol FE. Confiabilidade de escalas de Comprometimento neurológico em pacientes com acidente vascular cerebral. Arq Neuropsiquiatr. 2006;64(3):690-97.

12. Neder JA, Andreoni S, Lerario MC, Nery LE. Reference values for lung function tests. II. Maximal respiratory pressures and voluntary ventilation. Braz J Med Biol Res. 1999;32:719-27.

13. Sampaio, LMM et al. Força muscular respiratória em pacientes asmáticos submetidos ao treinamento muscular respiratório e treinamento físico. Revista Fisioterapia Universidade São Paulo. 2002;9(2):43-8.

14. Souza RB. Pressões respiratórias estáticas. In: Pereira, Carlos Alberto de Castro; Neder, José Alberto (Org.) Diretrizes para Testes de função pulmonary; 2002.155-65.

15. ATS: Guideline for the six-minute walk test. American Journal of Respiratory and Critical Care Medicine. 2002;166(1):111-7.

16. Burneto AF. Comparação entre a escala modificada de Borg e a escala de Borg modificada análago visual aplicadas em pacientes com dispnéia. Rev Bras Ciênc Mov. 1989; 3(1):34-40.

17. Cordeiro PB, Fernandes PM. Abordagem fisioterapêutica no adulto com lesões encefálicas adquiridas. In: Moura EW, Campos e Silva PA. Fisioterapia: aspectos clínicos e práticos da reabilitação. São Paulo: Artes médicas Ltda. 2005;301-8.

18. Pompeu SMAA, Pompeu JE, Rosa M, Silva MR. Correlação entre função motora, equilíbrio e força respiratória pós Acidente Vascular Cerebral. Rev Neurocienc. 2011;19(4):614-20.
19. Salmela LT, Parreira VF, Britto RR, Brant CT, Inácio EP, Alcântara TO, et al. Respiratory Pressures and Thoracoabdominal Motion in Community Dwelling Chronic Stroke Survivors. Arch Phys Med Rehabil. 2005;86:1974-8.

20. Ramos OS, Silva A. Fisioterapia Respiratória em Pacientes Neurológicos Adultos. In: Moura EW, Silva PAC. Fisioterapia-Aspectos Clínicos e Práticos da Reabilitação. São Paulo: Artes Médicas; 2005.561-71.

21. Simões RP, Castello V, Auad MA, Dionísio J, Mazzonetto M. Força muscular respiratória e sua relação com a idade em idosos de sessenta a noventa anos. RBCEH. 2010;7(1):52-61.

22. Fernandes FE, Martins SRG, Bonvent JJ. Efeito do Treinamento Muscular Respiratório por Meio do Manovacuômetro e do Threshold Pep em Pacientes Hemiparéticos Hospitalizados IFMBE Proceedings. 2007;18:1199-202.

23. Corrêa FI, Soares F, Andrade DV, Gondo RM, Peres JA, Fernandes AO, Corrêa JCF. Atividade muscular durante a marcha após acidente vascular encefálico. Arq. Neuropsiquiatria. 2005;63(3-B):847-51.

24. Perry J. Análise da Marcha: Marcha Patológica. São Paulo: Manole; 2005.

25. Vasconcellos JAC, Britto RR, Parreira VF, Cury AC, Ramiro SM. Pressões respiratórias máximas e capacidade funcional em idosas assintomáticas. Fisioterapia em Movimento. 2007; 20(3):93-100.

26. Forjaz CLM, Tinucci T. A medida da pressão arterial no exercício. Revista Brasileira de Hipertensão. 2007(1):79-87.

27. Macko RF, DeSouza CA, Tretter LD, Silver KH, Smith GV, Anderson PA et al. Treadmill aerobic exercise reduces the energy expenditure and cardiovascular demands of hemiparetic gait in chronic stroke patients. Stroke. 1997;28:326-30.

28. Abreu CM, Beck DGS, Vale PHC. Treinamento da musculatura inspiratória em indivíduos normais e portadores de patologias respiratórias. Fisioterapia em Movimento. 2000;12(2):141-52. 
29. Macko RF, Smith GV, Dobrovolny CL et al. Treadmill training improves fitness reserve in chronic stroke patients. Arch Phys Med Rehabil. 2001;82,879-84.

30. Luft AR, Macko RF, Forrester LW et al. Treadmill Exercise Activates subcortical neural networks and improves walking after stroke: a randomized controlled trial. Stroke. 2008;39: 3341-50.

Recebido: $10 / 09 / 2013$

Received: 09/10/2013

Aprovado: 26/06/2015

Approved: 06/26/2015 